\title{
Diagnostikk av kronisk hepatitt B-infeksjon
}

\begin{abstract}
BAKGRUNN Infeksjon med hepatitt B-virus kan føre til kronisk leverbetennelse med risiko for utvikling av cirrhose og leverkreft. Økt kunnskap og bedre behandling av kronisk hepatitt $\mathrm{B}$-infeksjon i de senere år gjør at virologiske tester i økende grad benyttes for å anslå sykdomsforløp, status og respons på behandling hos den enkelte pasient. Hensikten med denne oversikten er å gi en oppdatert oversikt over tilgjengelig diagnostikk.
\end{abstract}

KUNNSKAPSGRUNNLAG Artikkelen er bygd på et utvalg av original- og oversiktsartikler identifisert ved søk i Medline samt erfaringer fra mikrobiologisk diagnostikk ved nasjonalt referanselaboratorium for hepatittvirus i Norge.

RESULTATER Påvisning av virusproteiner og antistoffer mot disse samt viruskvantitering og -karakterisering er en viktig del av utredningen av hepatitt B-virusinfeksjon, heri inkludert stadfesting av sykdomsfase ved kronisk infeksjon.

FORTOLKNING God diagnostikk er basert på et bredt utvalg av ulike serologiske og virologiske markører. Genotype og enkelte mutasjoner kan påvirke sykdomsforløp og behandlingsrespons. For å kunne forebygge videre smitte og tilby effektiv behandling er det er viktig å identifisere kroniske bærere og personer med tidligere gjennomgått hepatitt B-virusinfeksjon med risiko for reaktivering.

Hepatitt B-virusinfeksjon kan føre til kronisk leverbetennelse, med risiko for utvikling av cirrhose og leverkreft og derav for tidlig død (1). På verdensbasis lever mer enn 240 millioner mennesker med kronisk infeksjon, og årlig dør anslagsvis 600000 mennesker som følge av dette (2). Hepatitt Bvirus smitter først og fremst via blod og seksuell kontakt og fra mor til barn i forbindelse med fødselen (3, 4). Hepatitt B-infeksjon kan gi ulike sykdomsforløp, avhengig av alder ved smittetidspunktet. Smitte ved fødsel medfører oftest at infeksjonen blir kronisk. Andelen som får kronisk infeksjon avtar med økende alder, og voksne får som regel en forbigående akutt infeksjon, med eller uten symptomer $(3,4)$. Innføring av hepatitt B-vaksinasjon av barn har redusert forekomsten av kronisk infeksjon i mange land, men sykdomsbyrden globalt er fortsatt stor $(3,4)$.

I de senere år er det gjort betydelige fremskritt i behandlingen av pasienter med kronisk hepatitt B-infeksjon $(1,5)$. Det er viktig å identifisere kroniske bærere for effektivt å kunne forebygge videre smitte og følge den enkelte pasient. I Norge gjelder det spesielt innvandrere fra mellom- og høyendemiske områder for hepatitt B-infeksjon som ble smittet som barn (6). Det er spesielt viktig at gravide i denne gruppen blir undersøkt, slik at vaksinasjon og spesifikt hepatitt B-immunglobulin kan gis til den nyfødte (3). Dessuten bør gravide med høy viruskonsentrasjon følges opp med tanke på behandling i siste trimester, for å redusere risikoen for smitte ytterligere (1).

Både akutt og kronisk hepatitt B-infeksjon er meldepliktig til Meldingssystem for smittsomme sykdommer (MSIS) (7). Det er meldt ca. 12000 tilfeller av kronisk hepatitt B-infeksjon i Norge fra 2002 og frem til i dag, men ut fra antall innvandrere født i høyendemiske områder antas tallet å være høyere (6). De siste årene er det meldt under hundre akutte tilfeller årlig (7), først og fremst injiserende stoffmisbrukere og deres seksualkontakter (6).

Forløpet av hepatitt B-infeksjon påvirkes av både virale faktorer, vertsfaktorer og koinfeksjon med hiv, hepatitt C-virus og hepatitt D-virus (1). Målet med denne artikkelen er å gi en oppdatert oversikt over tilgjengelig diagnostikk $\mathrm{i}$ forbindelse med utredning av sykdomsstatus og videre oppfølging av den enkelte pasient.

\section{Kunnskapsgrunnlag}

Det ble gjennomført søk i Medline, begrenset til artikler publisert de siste fem år. Søkeordene «chronic hepatitis B infection» ble kombinert med følgende: diagnostics, treatment, occult infection, anti-HBc alone, reactivation, genotype, precore, mutations.

Relevante artikler ble valgt ut på skjønnsmessig grunnlag. Søket ble avsluttet 31.9. 2012. I tillegg er retningslinjene til European Association for the Study of the Liver (ESAL) for oppfølging og behandling av kronisk hepatitt $\mathrm{B}$-infeksjon (1) og vår erfaring fra referanselaboratorium for hepatitt B-virus i Norge lagt til grunn.

\section{Hepatitt B-virusgenomet} trådet DNA-virus $(3,2 \mathrm{~kb})$ tilhørende hereplikasjonsmekanisme som foregår via et
Hepatitt B-viruset er et lite, delvis dobbeltpadnavirusfamilien (8). Viruset har en unik

\author{
Kathrine Stene-Johansen \\ kathrine.stene-johansen@fhi.no \\ Regine Barlinn \\ Avdeling for virologi \\ Folkehelseinstituttet
}

Se også kunnskapsprøve

på www.tidsskriftet.no/quiz

e-tab 3 finnes i Tidsskriftets elektroniske utgaver

HOVEDBUDSKAP

Kroniske bærere av hepatitt B-virus må identifiseres og vurderes av spesialisthelsetjenesten for videre oppfølging og eventuell behandling

Virologiske faktorer og immunrespons er av betydning for sykdomsforløp og behandlingsrespons

Behandlingseffekt må overvåkes og årsaken til eventuell behandlingssvikt identifiseres

Reaktivering av tidligere gjennomgått infeksjon kan forekomme ved immunsuppresjon eller immunmodulerende behandling 


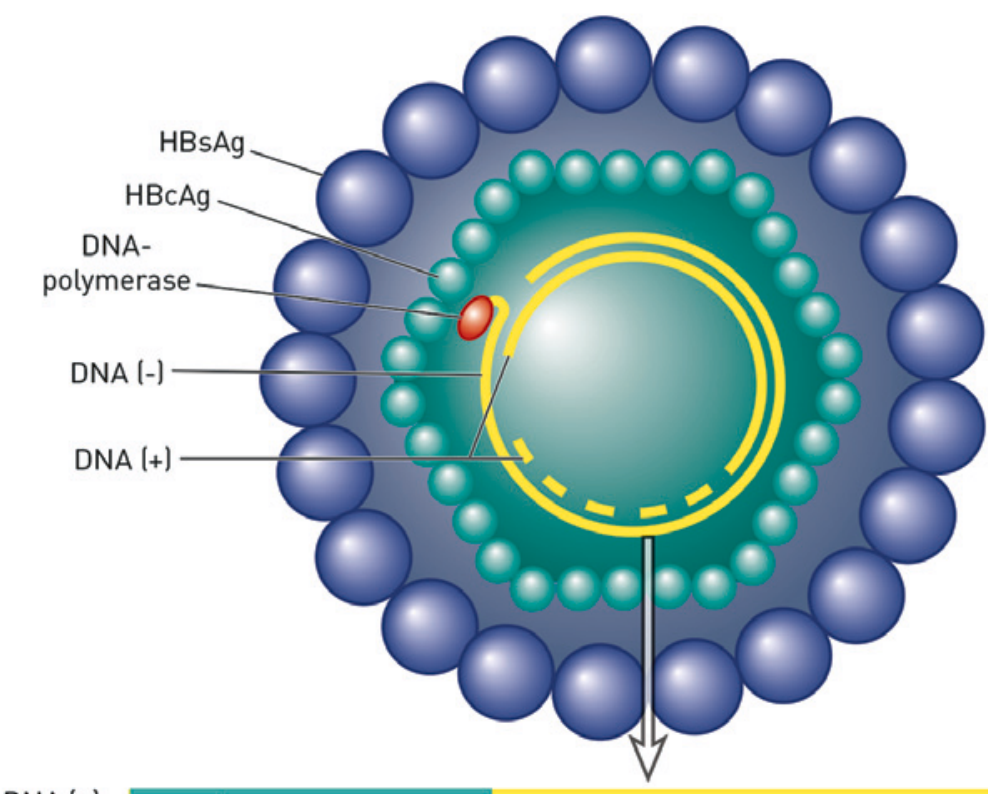

DNA [- $]$

\begin{tabular}{|rrr|}
\hline \multicolumn{1}{|c}{ Gen } & Leserammer for virusets proteiner & \multicolumn{1}{c|}{ Protein } \\
\hline Precore/core-genet: & & Precore/core (HBe/cAg) \\
P-genet: & Polymerase (Pol) \\
X-genet: & X-proteinet (HBx) \\
S-genet: & & Overflate (surface) (HBsAg) \\
\hline
\end{tabular}

(c) K. C. Toverud

Figur 1 Oppbygning av et hepatitt-B-virus og skjematisk fremstilling av dets genom. Virusets DNA koder for en innerkappe av kjerneprotein (HBCAg) og en ytre membran av overflateprotein (HBsAg), en polymerase og de ikke-strukturelle proteinene Xog $\mathrm{HBeAg}$

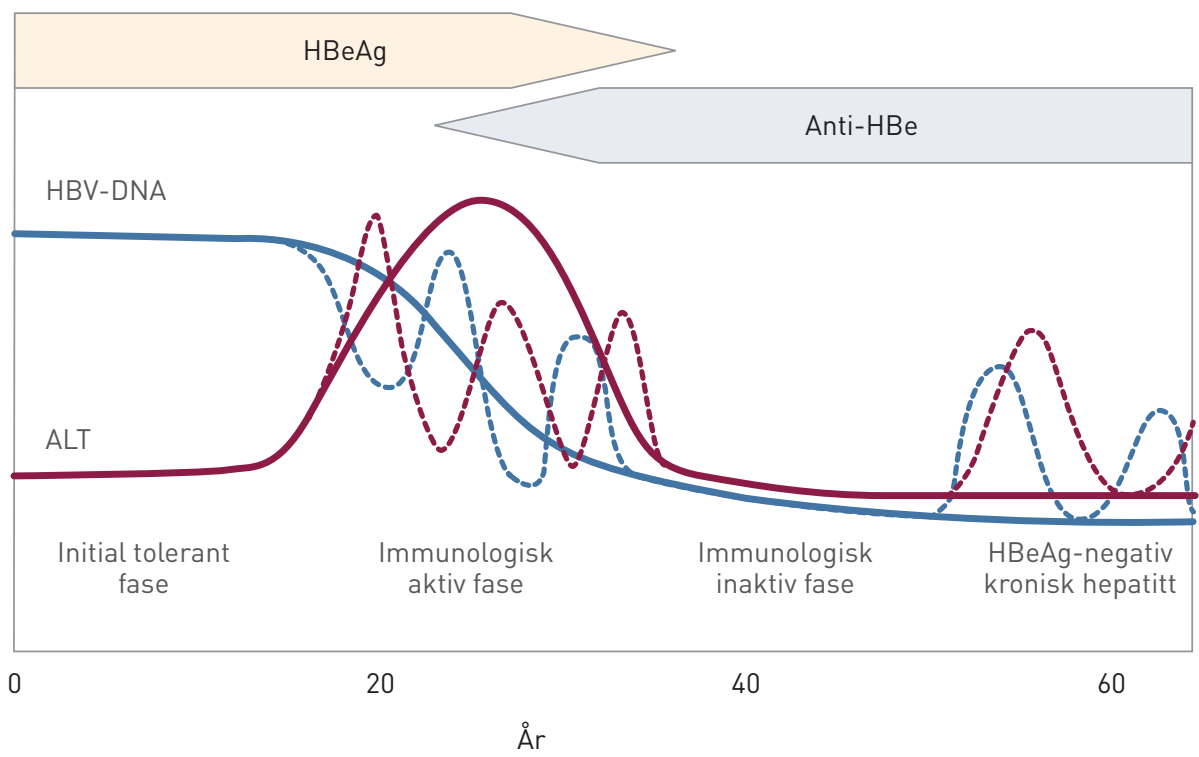

Figur 2 Kronisk infeksjon deles inn i ulike faser: Initial tolerant fase: høy viruskonsentrasjon og HBeAg i blod med eller uten beskjedne tegn på leverinflammasjon. Immunologisk aktiv fase: svingende, avtakende viruskonsentrasjon, serokonversjon til anti-HBe i siste fase og mer eller mindre tegn til leverinflammasjon. Immunologisk inaktiv fase: vanligvis lav viruskonsentrasjon, normale leververdier og anti-HBe-positiv. HBeAg-negativ kronisk hepatitt: Pasienter $i$ denne fasen er vanligvis eldre og har en mer fremskreden leversykdom stabilt mikrokromosom (cccDNA) i kjernen av levercellene.

Den genetiske informasjonen finnes på DNA-minustråden i fire overlappende leserammer som koder for virusets proteiner $-\mathrm{S}$ genet koder for overflateproteiner (surface) (HBsAg), som danner en ytre membran, precore-/core-genet koder for kjerneproteinet (core) ( $\mathrm{HBcAg}$ ), som danner en strukturell kappe, samt det ikke-strukturelle proteinet $\mathrm{HBeAg}, \mathrm{X}$-genet koder for et lite, regulatorisk X-protein og P-genet koder for en polymerase med revers transkriptase-aktivitet (8) (fig 1). Flere av virusets proteiner og gener benyttes ved diagnostisering av hepatitt Binfeksjon og utredning av sykdomsstatus.

\section{Utredning ved kronisk hepatitt B-infeksjon}

Et komplekst samspill mellom ulike vertsfaktorer og virologiske faktorer fører til at noen blir friske bærere uten leverpåvirkning, mens andre utvikler kronisk aktiv hepatitt $(1,5)$. Kroniske bærere bør derfor følges regelmessig. Kronisk hepatitt B-infeksjon defineres som tilstedeværelse av HBsAg (virusets overflateprotein) i serum i mer enn seks måneder. Tilstanden kan deles inn i sykdomsfaser (fig 2) (4), som kan utredes ved å kartlegge de ulike virologiske markørene (fig 2, tab 1). Anti-HBc-IgG opptrer tidlig etter smitten og vedvarer som regel livet ut. Anti$\mathrm{HBc}-\mathrm{IgM}$ kan forekomme $\mathrm{i}$ den aktive fasen av en kronisk infeksjon, men er først og fremst relevant ved akutt infeksjon. $\mathrm{HBeAg}$ er en markør for aktiv virusreplikasjon, og man skiller mellom HBeAg-positiv og $\mathrm{HBeAg-negativ} \mathrm{kronisk} \mathrm{infeksjon.} \mathrm{Tilstede-}$ værelse av $\mathrm{HBeAg}$ (HBeAg-positiv) angir vanligvis høy virusproduksjon og stor smittefare, mens tilstedeværelse av anti-HBe (HBeAg-negativ) vanligvis angir lav virusproduksjon og dermed lavere smittefare. Imidlertid kan $\mathrm{HBeAg}$-negative pasienter ha forhøyet viruskonsentrasjon som følge av mutasjoner i kjerneregionen (precore/coreregionen) $(1,5)$.

Viruskvantitering er en den viktigste markøren for å følge en kronisk infeksjon og overvåke effekt av behandling samt for å påvise okkulte infeksjoner og reaktivering ved immunsuppresjon. Viruskonsentrasjon oppgis i IU/ml (international units, IU). Sanntids-PCR anbefales for kvantitering av viruskonsentrasjon $\mathrm{i}$ blod på grunn av testens meget høye sensitivitet (10-20 IU/ml), spesifisitet og store måleområde $\left(10-10^{8}\right.$ $\mathrm{IU} / \mathrm{ml})(1)$.

\section{Anti-HBc-alene-positive og okkulte hepatitt B-virusinfeksjoner}

Tidligere antok man at pasienter med et serologisk mønster tilsvarende tidligere gjennomgått infeksjon (tab 1) var fri for virus, 
Tabell 1 Oversikt over diagnostiske markører og sannsynlig status ved hepatitt B-infeksjon

\begin{tabular}{|c|c|c|c|c|c|c|c|}
\hline & $\mathrm{HBsAg}$ & Anti-HBs & Anti-HBc-IgM & Anti-HBc-lgG & $\mathrm{HBeAg}$ & Anti-HBe & Viruskvantitering \\
\hline Uinfisert & - & - & - & - & - & - & - \\
\hline Immunitet etter vaksinasjon & - & + & - & - & - & - & - \\
\hline Akutt infeksjon & + & - & + & + & + & - & Høy \\
\hline Kronisk infeksjon (HBeAg-positiv) & + & - & $-/+$ & + & + & - & Нøу \\
\hline Kronisk infeksjon (HBeAg-negativ) & + & - & $-/+$ & + & - & + & Varierer lav/høy \\
\hline Tidligere gjennomgått infeksjon & - & + & - & + & - & $+/-$ & - \\
\hline «Core-alene» & - & - & - & + & - & $+/-$ & Meget lav \\
\hline Okkult hepatitt B-virusinfeksjon & - & $+/-$ & - & + & - & $+/-$ & Meget lav \\
\hline
\end{tabular}

men det har vist seg at virusets DNA ofte kan påvises i levercellene selv om HBsAg og virus ikke lar seg påvise i blodet (9).

Forklaringen på dette synes å være at virus fortsatt eksisterer i levercellen i form av et mikrokromosom. Dette er vist både direkte ved viruspåvisning i lever og indirekte ved at smitte er blitt overført fra HBsAg-negative/ anti-HBc-IgG-positive leverdonorer til mottaker av organet (10). Etter gjennomgått infeksjon ser man en gradvis reduksjon av antistoffene over år (anti-HBe, anti-HBs og anti-HBc).

Anti-HBc er som regel påvisbart hele livet. Det er ikke uvanlig at anti-HBc påvises uten anti-HBs, også kalt «core-alene» (11). Studier har vist at $1,7-8,1 \%$ av de anti-HBcalene-positive har lave viruskonsentrasjoner i blod og i større grad påvisbart virus i levervev $(9,12)$. Hepatitt B-virusinfeksjon med meget lav, men påvisbar viruskonsentrasjon i blod (< $200 \mathrm{IU} / \mathrm{ml})$, men uten påvisbar HBsAg med eller uten påvisbart anti-HBs kalles okkult (eller kryptisk) infeksjon. Den lave viruskonsentrasjonen indikerer lav smittsomhet. Okkult infeksjon forekommer hovedsakelig hos pasienter som er anti-HBcalene-positive (13). Den kliniske betydning for den enkelte pasient er fortsatt uklar (1).

Utredning og overvåking av okkult infeksjon bør utføres hos beinmargs- og organmottakere med tidligere hepatitt B-infeksjon, hos «core-alene»-pasienter med forhøyet ALAT, hos hemodialysepasienter, ved koinfeksjon med hiv og hepatitt C-virus samt ved fare for reaktivering $(14,15)$. Det er viktig å merke seg at hos immunkompromitterte personer, for eksempel hemodialysepasienter, kan markørene være avvikende eller manglende i forhold til det mønsteret man observerer hos friske.

\section{Reaktivering}

Reaktivering kjennetegnes ved leverinflammasjon og stigende viruskonsentrasjon i blodet. Dette er vanligst forekommende ved
HBeAg-negativ kronisk hepatitt, men kan også forekomme hos personer med tidligere gjennomgått infeksjon eller okkult infeksjon. Hos sistnevnte gruppe utløses reaktiveringen av endringer $\mathrm{i}$ immunfunksjonen $\mathrm{i}$ forbindelse med kjemoterapi eller immunmodulerende behandling (ved kreftsykdommer, autoimmune sykdommer, organtransplantasjon, beinmargstransplantasjon), koinfeksjon med hiv eller plutselig seponering av antivirale midler (16). Fordi reaktivering er en potensielt alvorlig tilstand som kan føre til fulminant hepatitt, bør alle pasienter som vurderes for immunsuppressiv eller immunmodulerende behandling testes for hepatitt B-virusmarkører (16).

Hvilke markører som påvises og grad av immunsuppresjon er avgjørende for den videre oppfølging (1). Profylaktisk behandling bør igangsettes før start av immunhemmende behandling og vedvare en tid etter seponering (16).

\section{Koinfeksjon}

Koinfeksjon med hiv, hepatitt C-virus eller hepatitt D-virus kan gi et mer aggressivt sykdomsforløp (1). Koinfeksjon er ikke uvanlig, ettersom hepatitt B-virus har felles smittevei med hiv, hepatitt C-virus og hepatitt D-virus. Det er viktig å undersøke for koinfeksjon først og fremst fordi det har innvirkning på den videre oppfølging og behandling, men koinfeksjon kan også påvirke de virologiske markørene (1).

\section{Laboratorieundersøkelser i forbindelse med behandling}

Høy viruskonsentrasjon er assosiert med økt risiko for utvikling av cirrhose og hepatocellulært karsinom $(5,17,18)$. Det er gjort fremskritt $\mathrm{i}$ behandlingen av kronisk hepatitt Binfeksjon i de senere år. Utredning og oppfølging av behandlingen blir i økende grad skreddersydd for den enkelte pasient. Indikasjon for behandling bestemmes ut i fra sykdomsstadium, leverstatus og viruskonsentrasjon, men også ut fra andre virologiske parametre (tab 2) (1).

Pasienter kan behandles med interferon eller antivirale medikamenter (nukleosid-/ nukleotidanaloger) $(1,5)$. Av sistnevnte er fem medikamenter (lamivudin, adefovir, entekavir, tenofovir, telbuvidin) godkjent per i dag, men ingen av disse eliminerer virus i levercellene (5). Derfor gis behandlingen over lengre tid for å holde virusproduksjonen på et lavest mulig nivå. Det er viktig å overvåke effekten av behandling med viruskvantitering ved oppstart og deretter regelmessig for å oppdage virusgjennombrudd. Rask reduksjon i HBsAg-nivå synes å indikere respons på behandling, spesielt gjelder dette for in-

Tabell 2 Analyser som er aktuelle ved utredning og overvåking ved behandling

\begin{tabular}{ll} 
Analyser & Tidspunkt for analyse \\
Viruskvantitering & Utredning, oppfølging og monitorering av behandling \\
HBeAg-og HBsAg-status & Utredning, oppfølging og behandlingsrespons \\
Genotyping & Utredning ved behandling \\
Mutasjoner i kjerneregionen & Utredning i utvalgte tilfeller \\
Resistenspåvisning & Virusgjennombrudd under behandling \\
\hline
\end{tabular}


terferonterapi (19). Kvantitering av HBsAg vurderes som en prognostisk markør for behandlingsrespons. Det foregår mange studier som vil avklare betydningen nærmere.

Ved økende viruskonsentrasjon under behandling bør man mistenke resistensutvikling. Virusresistens skyldes genetiske endringer som gjør at virus ikke hemmes av et medikament $i$ en konsentrasjon som normalt ville virke hemmende (18). Siden muterte virus kan formere seg på tross av behandling, selekteres disse frem (18). Antiviral behandling som gir fullstendig virussuppresjon hindrer utvikling av virusresistens, mens lavgradig virusreplikasjon gir seleksjonspress til fordel for resistente virus. Høy viruskonsentrasjon ved start av behandling, langsom virusreduksjon og tidligere suboptimal behandling er assosiert med høyere risiko for utvikling av resistens (1).

Virusets polymerase er angrepspunkt for samtlige av de fem antivirale medikamentene, der en eller flere forandringer av aminosyrene $i$ åtte ulike posisjoner er identifisert som direkte årsak til resistensutvikling (e-tab 3) (18). I enkelte tilfeller er det tilstrekkelig med én enkelt mutasjon for at viruset skal bli resistent (medikamentet har lav genetisk barriere), i andre tilfeller må flere mutasjoner være til stede for at resistensutvikling skal finne sted (medikamentet har høy genetisk barriere). Resistens mot medikamenter viruset tidligere ikke er eksponert for (kryssresistens) forekommer.

Entekavir og tenofovir er i dag førstelinjebehandling. De har høy genetisk barriere, gir effektiv virussuppresjon og er i liten grad assosiert med resistensutvikling (1). Lamivudin, telbuvidin og adefovir har lav genetisk barriere og fører ofte til resistensutvikling. Resistensbestemmelse kan være aktuelt ved dårlig eller manglede respons på behandling hos pasienter med god pasientetterlevelse, men sjelden før behandlingsstart (1).

Med dagens førstelinjebehandling er resistens sjeldent, selv etter fem års bruk (1). Alle virus som genotypes ved Folkehelseinstituttet overvåkes med tanke på medikamentell behandling og blir rapportert til Resistensovervåkning Av Virus i Norge (RAVN) (20). Det er vist at hepatitt B-virus som er resistente mot antivirale medikamenter kan overføres fra person til person (21).

\section{Hepatitt B-virusvarianter}

Høy mutasjonsrate, kort replikasjonstid og høy virusproduksjon bidrar til en heterogen viruspopulasjon i verten, og over tid vil virusmutanter selekteres $(8,22)$. Det er i økende grad grunnlag for å hevde at ulike virologiske faktorer, slik som genotype og enkelte mutasjoner $\mathrm{i}$ både overflategenet og kjerneregionen, påvirker sykdomsforløp og respons på behandling $(8,22,23)$. Ved utredning av en kronisk hepatitt B-infeksjon kan det være aktuelt å undersøke for slike varianter.

\section{Genotyper}

Hepatitt B-viruset klassifiseres i ulike genotyper (A-J) basert på den genetiske variasjonen hos viruset (23). Genotypene A og D er relativt utbredt og forekommer i Afrika samt i store deler av Asia og Europa, mens genotype D dominerer spesielt i Middelhavsområdet (23). Genotypene $\mathrm{B}$ og $\mathrm{C}$ dominerer $\mathrm{i}$ Sørøst-Asia og Stillehavsområdet. Genotype E finner man i Vest-Afrika, mens genotypene F og H er mest vanlig i Mellom- og Sør-Amerika. Genotypene G-J er foreløpig sjeldne.

Migrasjon er en viktig faktor i genotypenes utbredelse. I lavendemiske områder gienspeiler forekomsten av ulike genotyper innvandrerpopulasjonen fra områder som er høyendemiske for hepatitt B-infeksjon. De vanligste genotypene (A-D) er derfor tilsvarende utbredt i Nord-Amerika, Europa og Australia (23). I Norge ligger forekomsten av hver av de enkelte genotypene A-D på $20-30 \%$, forekomsten av genotype $\mathrm{E}$ er på $<10 \%$, mens genotypene $\mathrm{F}-\mathrm{H}$ sjelden påvises (24).

Studier indikerer at genotype kan ha betydning for sykdomsforløp og behandlingsrespons (23). Genotypene A og B synes å gi bedre behandlingsrespons enn genotypene $\mathrm{C}$ og $\mathrm{D}$ ved behandling med interferon hos $\mathrm{HBeAg}$-positive pasienter (23, 25), mens det ikke er noen sammenheng mellom genotype og respons ved behandling med nukleosid-/nukleotidanaloger (1, 26). I hovedtrekk synes genotypene A og B å innebære et mildere sykdomsforløp enn genotype $\mathrm{C}$ og genotype $\mathrm{D}$, og det er økende dokumentasjon for at genotype $\mathrm{C}$ gir senere $\mathrm{HBeAg-serokonversjon} \mathrm{og} \mathrm{raskere} \mathrm{progre-}$ diering til cirrhose og hepatocellulært karsinom enn genotype $\mathrm{B}(17,22,23,26)$.

\section{Mutasjoner i kjerneregionen}

Hos mange $\mathrm{HBeAg}$-negative pasienter finner man persisterende eller intermitterende høye viruskonsentrasjoner, noe som er assosiert med kronisk inflammasjon i lever og progredierende fibrose. Denne formen kalles $\mathrm{HBeAg}$ negativ kronisk hepatitt B-infeksjon (1). Hos disse pasientene finner man ofte mutasjoner $\mathrm{i}$ kjerneregionen som fører til en nedregulering eller blokkering av HBeAg-produksjonen. De vanligste mutasjonene er dobbeltmutasjonen A1762T/G1764A i promotorregionen og G1896A i kjerneregionen. Studier viser at dobbelmutasjon A1762T/G1764A er assosiert med betydelig økt risiko for cirrhose og utvikling av hepatocellulært karsinom $(17,22)$, mens betydningen av mutasjon G1896A er mer usikker. Det er også vist at $\mathrm{HBeAg}$-positive pasienter med disse mutasjonene responderer dårligere enn pasienter med villtypemutasjoner på behandling med interferon (27).
HBeAg-negativ kronisk infeksjon kan stadfestes når $\mathrm{HBeAg}$ er negativ og anti$\mathrm{HBe}$ er positiv, transaminasene og viruskonsentrasjonen er forhøyet samt eventuelt ved påvisning av de respektive mutasjonene. Fluktuerende transaminaser og viruskonsentrasjon kan gjøre dette vanskelig å stadfeste, slik at pasientene må følges regelmessig over tid (1). Hos noen genotyper, slik som genotype A, er mutasjon G1896A ugunstig for viruset $\mathrm{g}$ forekommer i liten grad, mens genotype D ofte er assosiert med tidlig $\mathrm{HBeAg}$-serokonversjon, da denne mutasjonen forekommer hyppig (23).

\section{Mutasjoner i overflateantigen (HBsAg)}

Hepatitt B-vaksine er basert på virusets overflateantigen ( $\mathrm{HBsAg}$ ) og gir vanligvis langvarig beskyttelse mot sykdom ved fullvaksinering $(3,4)$. Smitte på tross av fullvaksinering kan skyldes dårlig beskyttelse etter vaksineringen eller at personen er smittet med en vaksinemutant. Vaksinestimulerte antistoffer gjenkjenner ikke vaksinemutanter på grunn av forandringer i virusets overflateprotein (8). Ved samtidig påvisning av HBsAg og anti-HBs i gjentatte prøver kan man mistenke smitte med vaksinemutant, da dette bildet ellers kun ses i omslagsfasen etter en akutt infeksjon. Utilstrekkelig beskyttelse etter vaksinasjon er mest sannsynlige årsak til smitte, da vaksinemutanter sjelden observeres hos pasienter med hepatitt Binfeksjon på tross av vaksinasjon (4).

Det er vist at mutasjoner i overflateantigenet påvirker HBsAg-testens sensitivitet (28). Dette gjelder både kvalitative tester som benyttes til bekreftelse og screening av hepatitt B-infeksjon og kvantitative tester (28). Overlappende leserammer (fig 1) gjør at resistensmutasjoner i polymerasen som følge av behandling også kan føre til redusert antigen-antistoff-binding.

\section{Konklusjon}

Kronisk hepatitt B-infeksjon kan føre til kronisk leverbetennelse med risiko for utvikling av cirrhose og leverkreft, men i de senere år er det kommet nye og mer effektive medikamenter for behandling av kronisk infeksjon og økt kunnskap om respons på behandling. Dette vil kunne bidra til at flere tilbys behandling.

Forekomsten av kronisk hepatitt B-infeksjon i Norge er sannsynligvis underestimert (6). Det er derfor viktig å identifisere kroniske bærere. Økende bruk av immunsupprimerende og immunmodulerende behandling til ulike pasientkategorier øker også behovet for overvåking av både kroniske bærere og pasienter med tidligere gjennomgått infeksjon med tanke på reaktivering. Alle kroniske bærere bør få kartlagt sykdomsstatusen og 
ved behov bli vurdert av spesialisthelsetjenesten med tanke på videre oppfølging og indikasjon for behandling. I den sammenheng er god diagnostikk viktig.

Folkehelseinstituttet er referanselaboratorium for hepatitt B-virus i Norge og utfører laboratoriebasert overvåking for å kartlegge mutasjoner og varianter som kan ha betydning for folkehelsen. Disse undersøkelsene vil også være av betydning for den enkelte pasient.

Vi takker kolleger ved Avdeling for virologi ved Folkehelseinstituttet for innspill $i$ forbindelse med gjennomlesing av artikkelen: Susanne Gjeruldsen Dudman, Gunnar Hoddevik, Rikard Rykkvin og Inger Sofie Samdal Vik.

\section{Kathrine Stene-Johansen (f. 1969)}

er ph.d. og forsker i molekylærvirologi i faggruppe for hepatittvirus.

Forfatter har fylt ut ICMJE-skjemaet og oppgir ingen interessekonflikter.

\section{Regine Barlinn (f. 1965)}

er spesialist i medisinsk mikrobiologi og overlege.

Forfatter har fylt ut ICMJE-skjemaet og oppgir ingen interessekonflikter.

\section{Litteratur}

. European Association For The Study Of The Liver. EASL clinical practice guidelines: Management of chronic hepatitis B virus infection. J Hepatol 2012 57: 167-85
2. WHO. Hepatitis B. Factsheet no. 204, 2012. www.who.int/mediacentre/factsheets/fs204/en/ (6.6.2012)

3. WHO. Hepatitis B vaccines. Wkly Epidemiol Rec 2009; 84: 405-19

4. Shepard CW, Simard EP. Finelli L et al. Hepatitis B virus infection: epidemiology and vaccination. Epidemiol Rev 2006: 28: 112-25

5. Kwon H, Lok AS. Hepatitis B therapy. Nat Rev Gas troenterol Hepatol 2011; 8: 275-84.

6. Rimšeliene G, Nilsen O, Kløvstad H et al. Epidemiology of acute and chronic hepatitis B virus infection in Norway, 1992-2009. BMC Infect Dis 2011; 11: $153-60$

7. Meldingssystem for smittsomme sykdommer (MSIS) www msis no (6.6.2013).

8. Locarnini S, Zoulim F. Molecular genetics of HBV infection. Antivir Ther 2010; 15 (suppl 3): 3-14

9. Knöll A, Hartmann A, Hamoshi H et al. Serological pattern «anti-HBc alone»: characterization of 552 individuals and clinical significance. World J Gastroenterol 2006: 12: 1255-60.

10. Dickson RC, Everhart JE, Lake JR et al. Transmission of hepatitis $B$ by transplantation of livers from donors positive for antibody to hepatitis B core antigen. Gastroenterology 1997: 113: 1668-74

11. Pondé RA, Cardoso DD, Ferro MO. The underlying mechanisms for the «anti-HBC alone» serological profile. Arch Virol 2010; 155: 149-58

12. Kang SY, Kim MH, Lee WI. The prevalence of «anti$\mathrm{HBC}$ alone» and HBV DNA detection among antiHBc alone in Korea. J Med Virol 2010; 82: 1508-14.

13. Raimondo G, Allain JP, Brunetto MR et al. Statements from the Taormina expert meeting on occult hepatitis B virus infection. J Hepatol 2008; 49: $652-7$.

14. Raimondo G, Pollicino T, Romanò L et al. A 2010 update on occult hepatitis B infection. Pathol Biol (Paris) 2010; 58: 254-7.

15. Chu CJ, Lee SD. Hepatitis B virus/hepatitis C virus coinfection: epidemiology, clinical features, viral interactions and treatment. J Gastroenterol Hepatol 2008; 23: 512-20.

16. Hoofnagle JH. Reactivation of hepatitis B. Hepatology 2009; 49 (suppl): S156-65

17. Taylor BC, Yuan JM, Shamliyan TA et al. Clinical outcomes in adults with chronic hepatitis B in association with patient and viral characteristics: A systematic review of evidence. Hepatology 2009 49 (suppl): S85-95.
18. Zoulim F, Locarnini S. Management of treatment failure in chronic hepatitis B. J Hepatol 2012; 56 (suppl 1): S112-22.

19. Liaw YF. Clinical utility of hepatitis B surface anti gen quantitation in patients with chronic hepatitis B: a review. Hepatology 2011; 54: E1 -9.

20. Resistensovervåkning Av Virus i Norge (RAVN). http://ravn.fhi.no/ (6.6.2013)

21. Locarnini S, Bowden S. Drug resistance in antivira therapy. Clin Liver Dis 2010; 14: 439-59.

22. Lin $\mathrm{CL}$, Kao JH. Hepatitis B viral factors and clinical outcomes of chronic hepatitis B. J Biomed Sci 2008; 15: 137-45

23. Tanwar S, Dusheiko G. Is there any value to hepatitis $B$ virus genotype analysis? Curr Gastroenterol Rep 2012; 14: 37-46.

24. Blystad H, Kløvstad H, Kostova V et al. Årsrapport 2011 for sykdomsprogrammet Blod-og seksuelt overførbare infeksjoner. Oslo: Folkehelseinstituttet, 2012

25. Sonneveld MJ, Rijckborst V, Cakaloglu Y et at. Durable hepatitis $B$ surface antigen decline in hepatitis $B$ e antigen-positive chronic hepatitis $B$ patients treated with pegylated interferon- $\alpha 2 b$ : relation to response and HBV genotype. Antivir Ther 2012: 17: 9-17.

26. Raimondi S, Maisonneuve $\mathrm{P}$, Bruno $\mathrm{S}$ et al. Is response to antiviral treatment influenced by hepatitis B virus genotype? J Hepatol 2010; 52: $441-9$

27. Sonneveld MJ, Rijckborst V, Zeuzem S et al. Presence of precore and core promoter mutants limits the probability of response to peginterferon in hepatitis $\mathrm{B}$ e antigen-positive chronic hepatitis B. Hepatology 2012; 56: 67-75.

28. Servant-Delmas A, Mercier-Darty M, Ly TD et al. Variable capacity of 13 hepatitis B virus surface antigen assays for the detection of HBsAg mutants in blood samples. J Clin Virol 2012; 53: 338-45.

Mottatt 19.10. 2012, første revisjon innsendt 8.3. 2013, godkjent 12.6. 2013. Medisinsk redaktør Kristin Viste. 